\title{
Passagem 002
}

\author{
Luciana Crepaldi Martins
}

E m março de 2006, a arquiteta e artista visual Luciana Crepaldi Martins, brasileira atualmente radicada em Barcelona, apresentava assim sua versão da conhecida obra de Leonardo da Vinci [figura 1]. Embora pareça recuperar certos elementos do Body Art dos anos 1970, uma das coisas que chama atenção na montagem, desde o ponto de vista do campo disciplinar da Arquitetura e Urbanismo, é certa idéia de compulsão pela apreensão e representação da realidade. Nesse trabalho, Crepaldi enuncia a idéia de superabundância, presente no processo de apreensão e representação da cidade, notadamente a partir da popularizacão das novas tecnologias da informação e comunicação, na década de 1990, mas igualmente nos mapas produzidos pelo Colégio dos Cartógrafos do Império:

\begin{abstract}
"... Naquele Império, a Arte da Cartografia atingiu uma tal perfeição que o mapa duma só Província ocupava toda uma Cidade, e o mapa do Império, toda uma Província. Com o tempo, esses Mapas Desmedidos não satisfizeram e os Colégios de Cartógrafos levantaram um Mapa do Império que tinha o tamanho do Império e coincidia ponto por ponto com ele". [BORGES, 1978 in: COSTA, 2005]
\end{abstract}

Devido a esta proximidade entre corpo, arquitetura e cidade, que sua obra inspira, Crepaldi foi convidada pela seção Passagens da Revista Thesis para realizar uma série de fotografias da cidade de Barcelona. Como referência para realizar a tarefa, foi dado como condição a de inspirar-se livremente, sem que indicássemos apontamentos ou materiais específicos, nos Trabalhos das Passagens, de Walter Benjamin. Entusiasmada pelo desafio, Crepaldi produziu centenas de fotografias que mostram uma cidade reencarnada numa espécie de devir que se havía perdido. Uma seleção dessas imagens resultou numa exposição na Galería Imaginart, na capital catalã.

A realização da seleção de imagens que aparece na Revista Thesis, teve como fundamento certa idéia de potencialização do impreciso: a fotografia, enquanto suporte visual, deveria ser capaz de absorver outros muitos enunciados e com eles sugerir uma terceira imagem. A partir dessa seleção, a editoria vinculou um título e uma citação a cada fotografia, retirados de "Apuntes y materiales" de Walter Benjamin e publicados no Libro de los Pasajes [BENJAMIN, 2013]. 


\begin{abstract}
"E, assim como as crianças não se cansam de transformar, com um só gesto, a bolsa e o que está dentro dela, numa terceira coisa - a meia - assim também Proust não se cansava de esvaziar com um só gesto o manequim, o Eu, para evocar sempre de novo o terceiro elemento: a imagem, que saciava sua curiosidade, ou sua nostalgia." [BENJAMIN, 1996]
\end{abstract}

Nesta aproximação, entre dois enunciados, procurouse estabelecer um estado de passagem e nele a Arquitetura como o terceiro enunciado. [Xico Costa]

BENJAMIN, Walter. A imagem de Proust. In: Obras escolhidas. São Paulo: Editora Brasiliense, 1996, p.39-40.

BENJAMIN, Walter. Libro de los pasajes [Edición de Rolf Tiedemann]. Madrid: Akal, 2013

BORGES, Jorge Luis Borges. Do Rigor na Ciência. In: História Universal da Infâmia". Porto Alegre: Editora Globo, 1978.

COSTA, Xico. Síntese gráfica. Funes, el memorioso, e o Colégio de Cartógrafos do Império. Drops, São Paulo, ano 05, n. 010.06, Vitruvius, mar. 2005 <http://www.vitruvius.com. br/revistas/read/drops/05.010/1643>. Acesso: 15/7/2015.

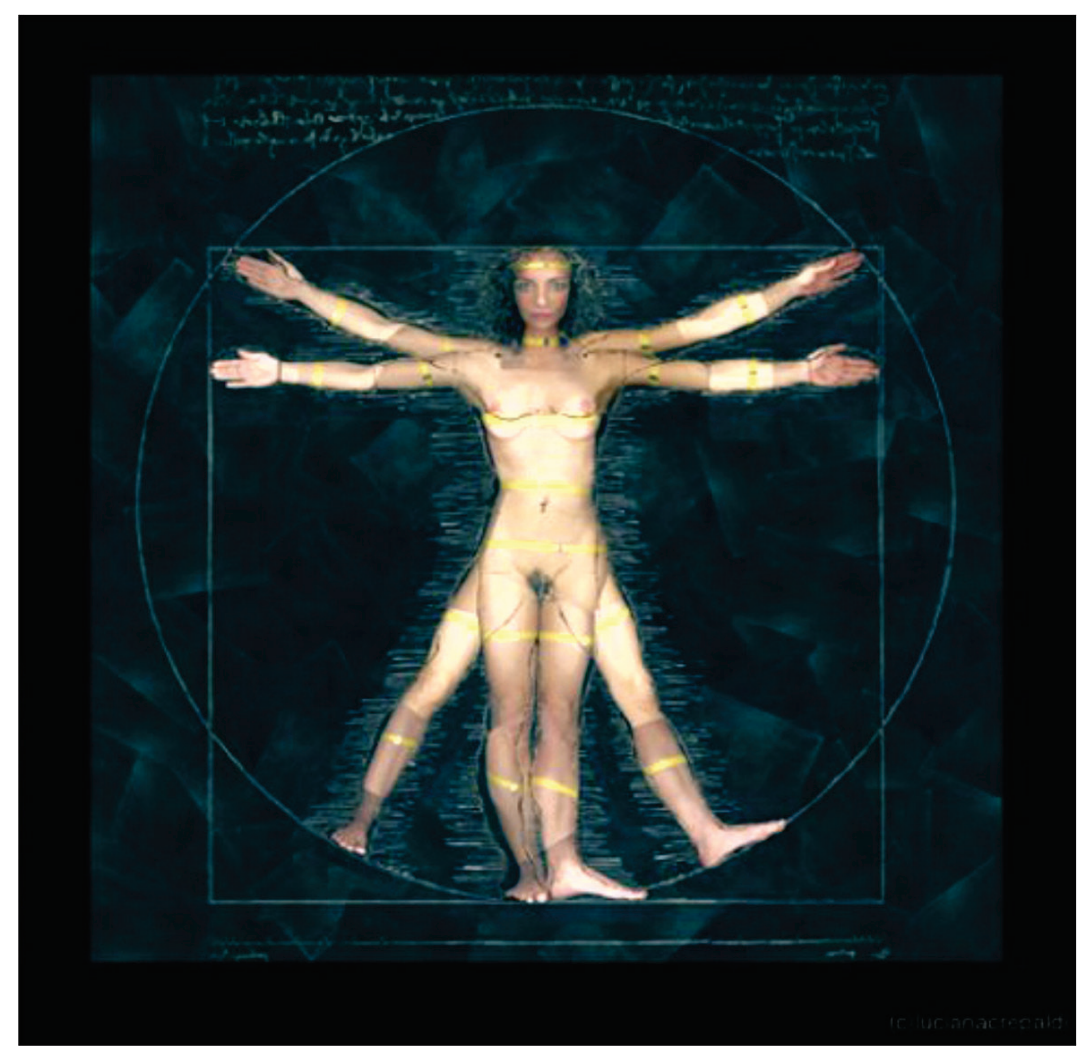

Figura 1

[fotografia: Luciana Crepaldi, 2014]

\section{La Divina proporción}




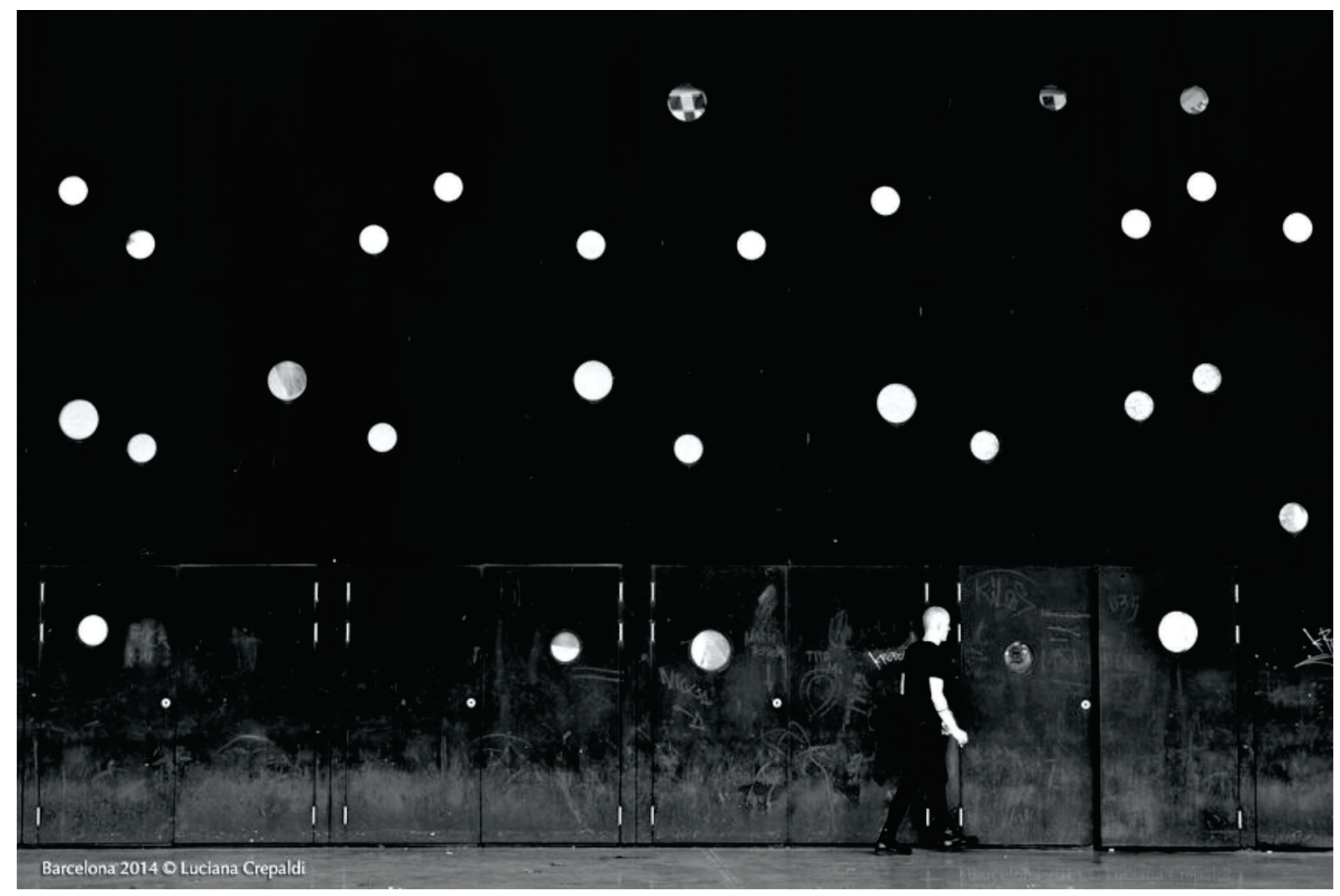

\section{Puertas}

"Estas puertas - la entrada a los pasajes - son umbrales. Ningún escalón de piedra los señala. Pero eso lo hace la actitud de espera de las pocas personas presentes. Sus pasos lentos y medidos reflejan, sin que ellas mismas lo sepan, que se está ante una decisión."

Obra de los pasajes [C 3, 6]. In: BENJAMIN, Walter. Libro de los pasajes [Edición de Rolf Tiedemann]. Madrid: Akal, 2013, p.115. 


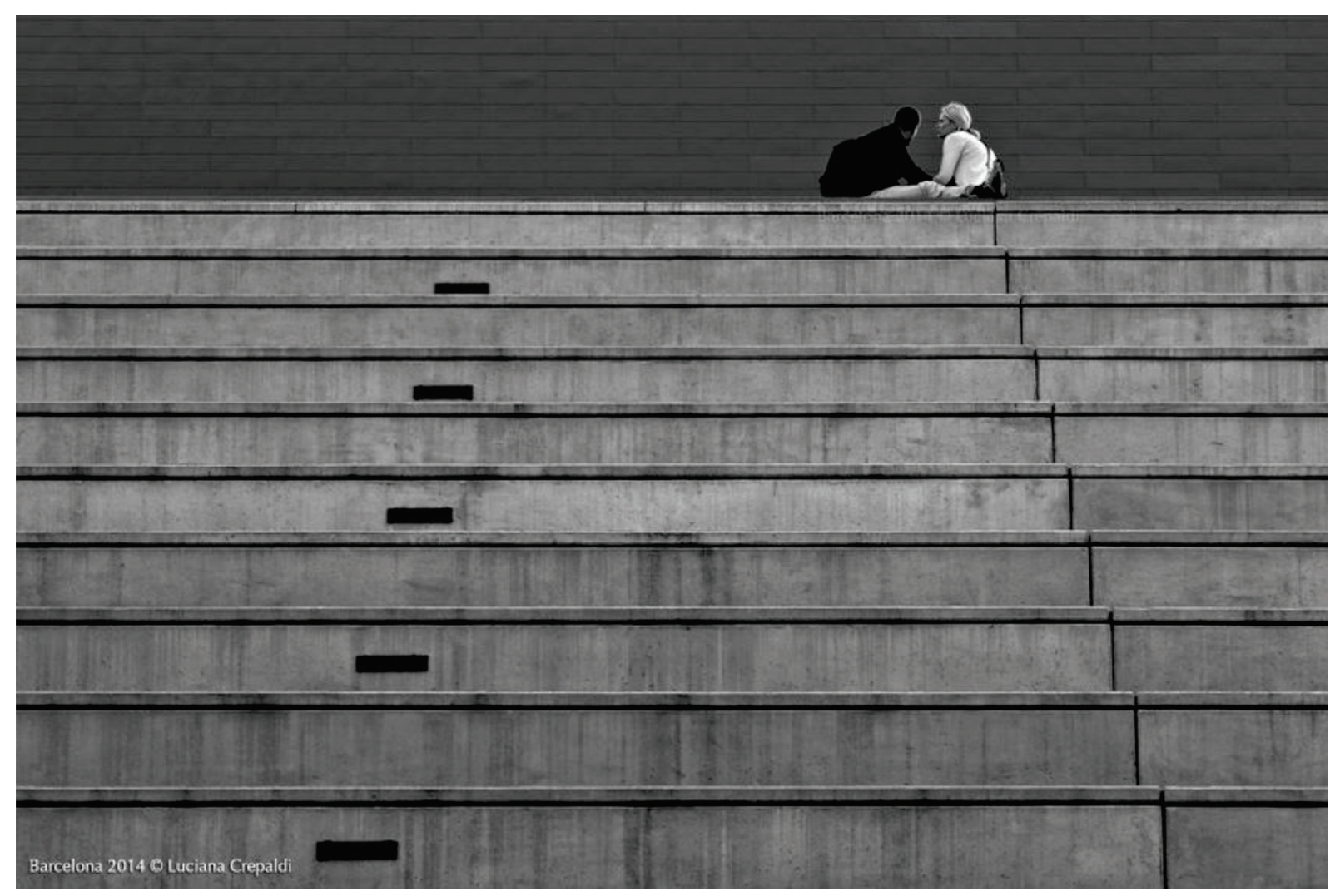

\section{Sectores}

"Sólo en apariencia es uniforme la ciudad. Incluso su nombre suena de distinta forma en sus distintos sectores. En ningún sitio, a no ser en los sueños, se experimenta todavía del modo más primigenio el fenômeno del límite como en las ciudades. Conocerlas supone saber de esas líneas que a lo largo del tendido ferroviario, a través de las casas, dentro de los parques o siguiendo la orilla del río, corren como líneas divisorias; supone conocer tanto esos límites como también los enclaves de los distintos sectores. Como umbral discurre el límite por las calles; una nueva sección comienza como un paso en falso, como si nos encontráramos en un esca 


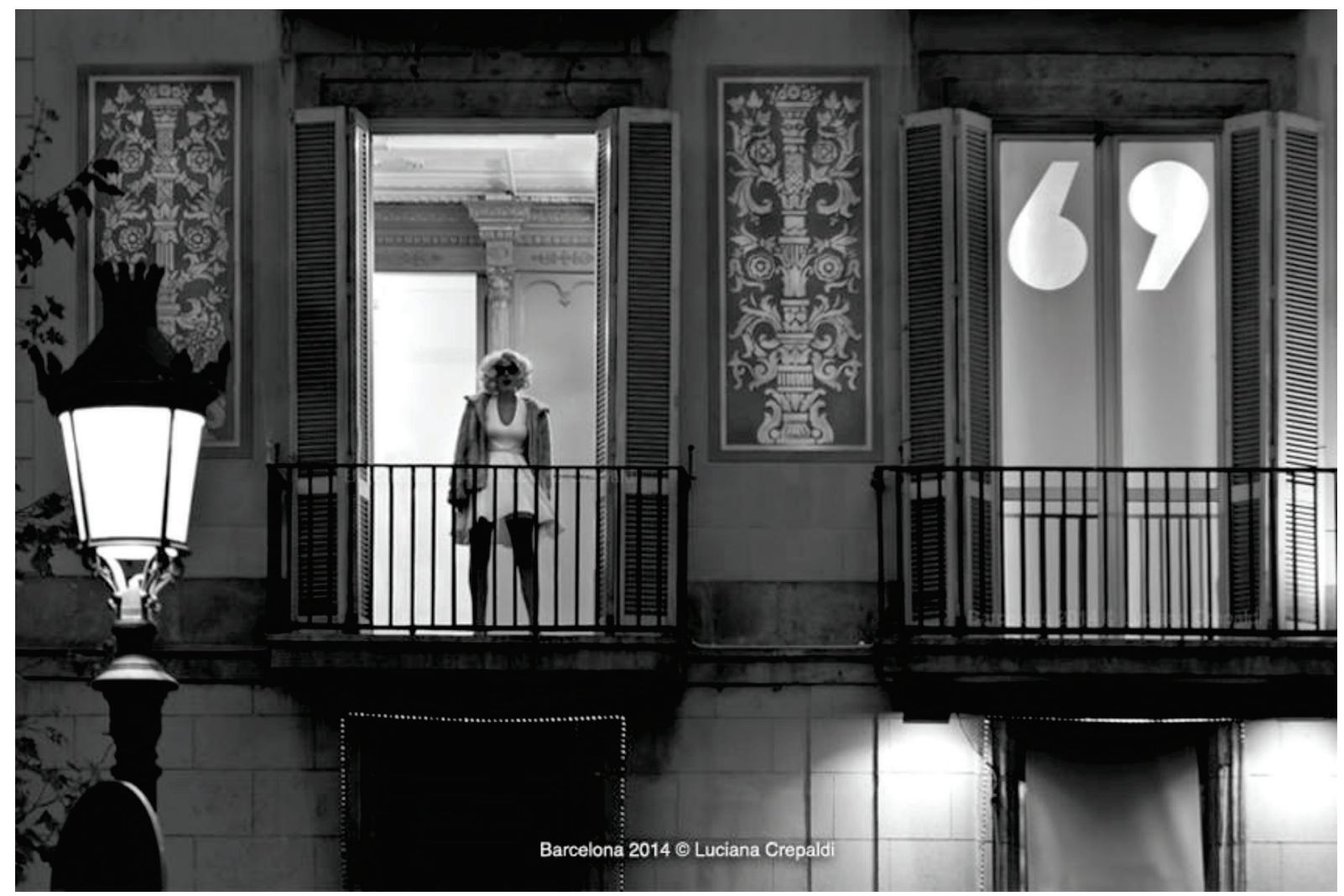

Ruínas

"Las ruínas de la Iglesia y de la Nobleza, las de la Feudalidad y de la Edad Media, son sublimes y Ilenan hoy de admiración a los sorprendidos y asombrados vencedores; pero las de la Burguesía serán un innoble detritus de cartón piedra, de escayolas y de colorines." Le diable à Paris, II, París, 1845, p.18. 


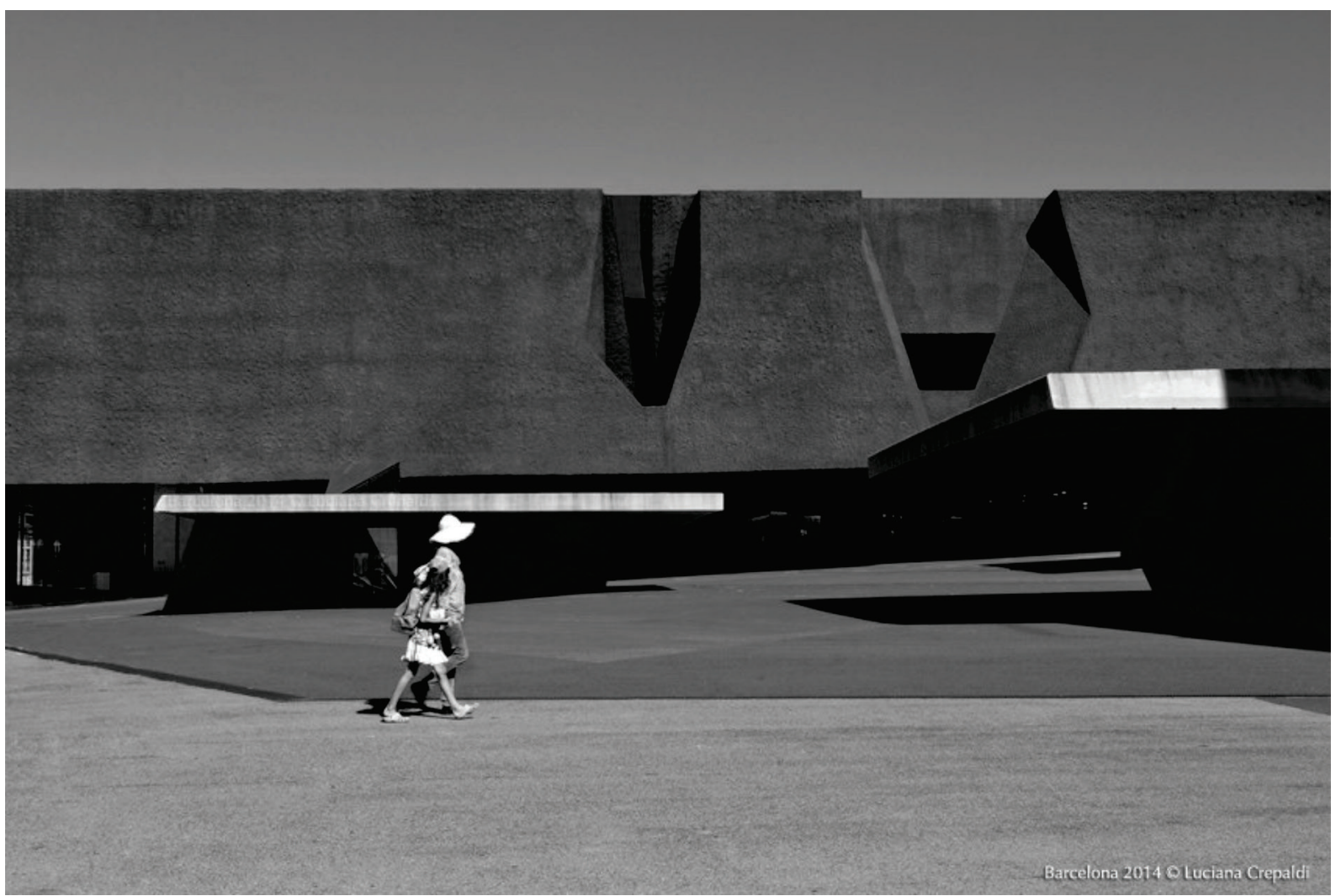

\section{Mercancía}

"Comercio y tráfico son los dos componentes de la calle. Pero resulta que el segundo há desaparecido en los pasajes; su tráfico es rudimentario. És solo calle ávida de comercio, que únicamente se presta a despertar los apetitos. Porque en esta calle los jugos dejan de fluir, la mercancía prolifera en sus márgenes descomponiéndose en fantásticas combinaciones, como los tejidos em las úlceras. El flâneur sabotea el tráfico. Tampoco es un comprador. Es mercancía." 


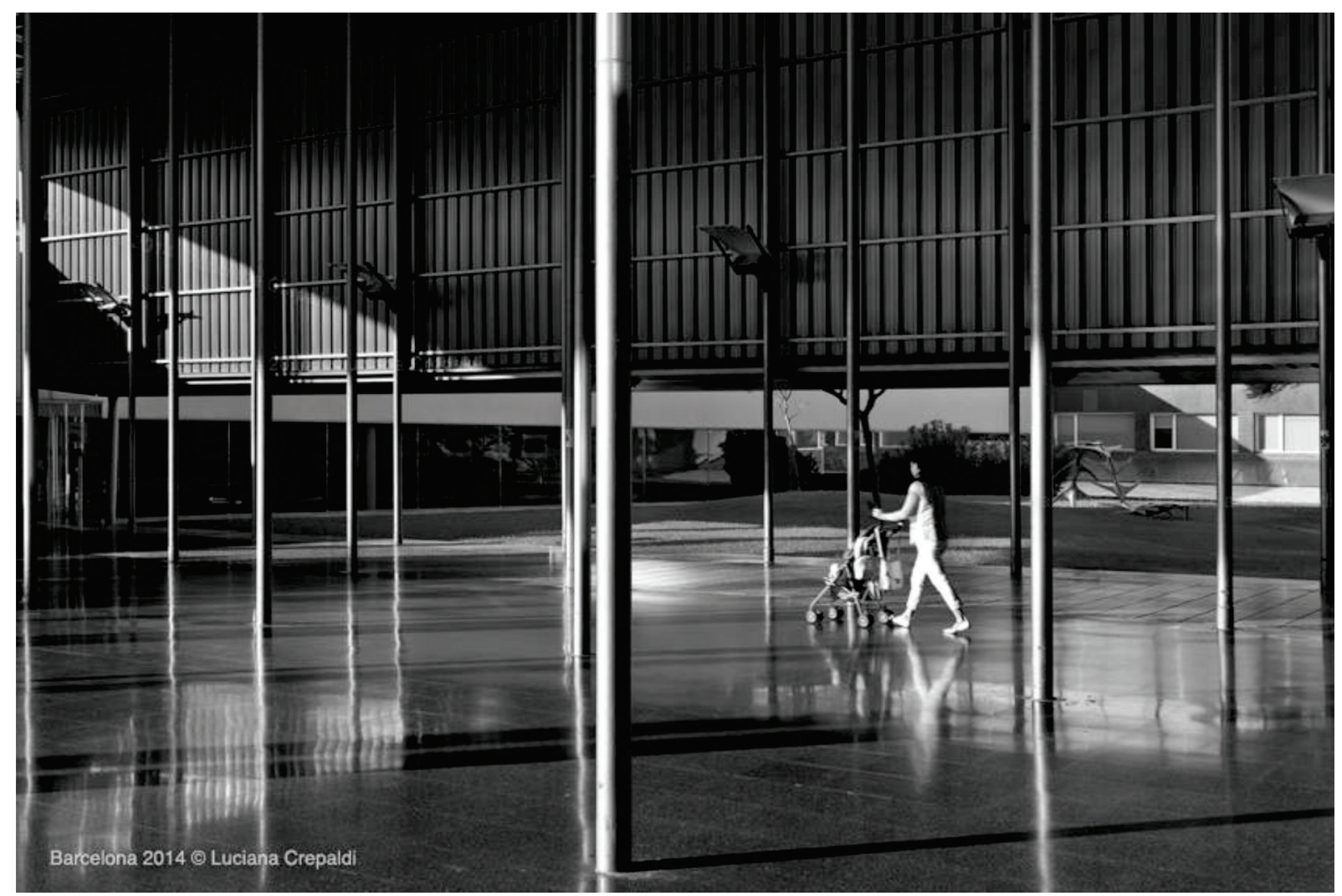

\section{Pensamiento unitario}

"Nuestro siglo enlazará el reino de la fuerza aislada, abundante en creaciones originales, con el reino de la fuerza uniforme, pero niveladora, que iguala los productos, arrojándolos en masa y obedece a un pensamiento unitario, expresión última de las sociedades."

H. de Balzac. L'illustre Gaudissart, París, ed. Calman-Lévy, p. 1 (1837).

Obra de los pasajes [C 2a, 8]. In: BENJAMIN, Walter. Libro de los pasajes [Edición de Rolf Tiedemann]. Madrid: Akal, 2013, p.89. 


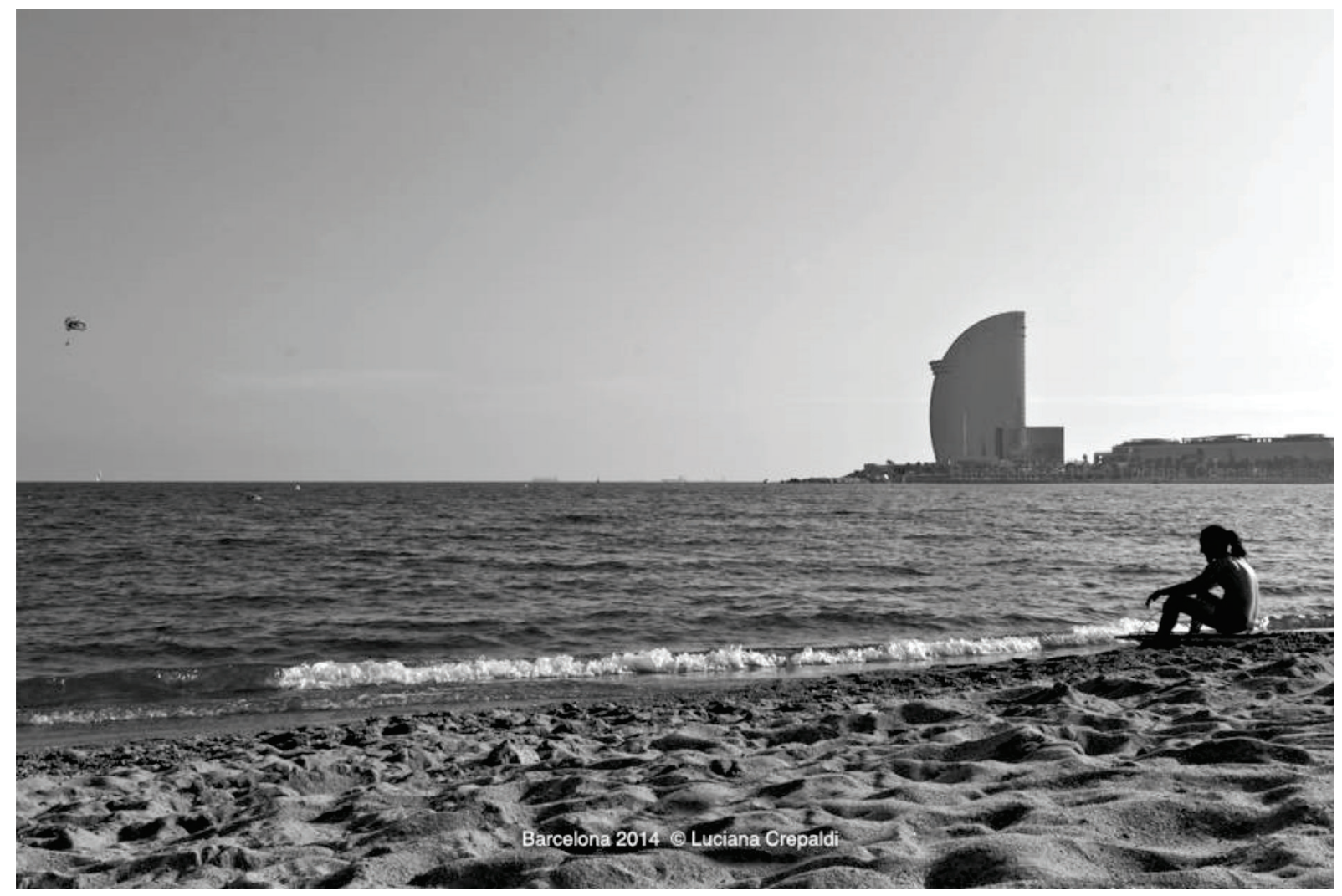

\section{Temporada}

"El más ardiente interés de la moda reside para el filósofo en sus extraordinarias anticipaciones. Es sabido que el arte, de muchas maneras, como por ejemplo en imágenes, se anticipa en años a la realidad perceptible. Se han podido ver calles o salones que resplandecían en fuegos multicolores antes de que la técnica, a través de los anuncios luminosos y otras instalaciones, los colocara bajo una luz semejante. De igual modo, la sensibilidad del artista por lo venidero llega mucho más allá que la de una gran señora. Y, sin embargo, la moda está en un contacto más constantes y preciso con las cosas venideras merced a la intuición incomparable que posee el colectivo feminino para aquello que el futuro há preparado. Cada temporada trae en sus más novedosas creaciones ciertas señales secretas de las cosas venideras. Quien supiese leerlas no sólo conocería por anticipado las nuevas corrientes artísticas, sino los nuevos códigos legales, las nuevas guerras y revoluciones. Aqui radica sin duda el mayor atractivo de la moda, pero también la dificultad para sacarle partido." 


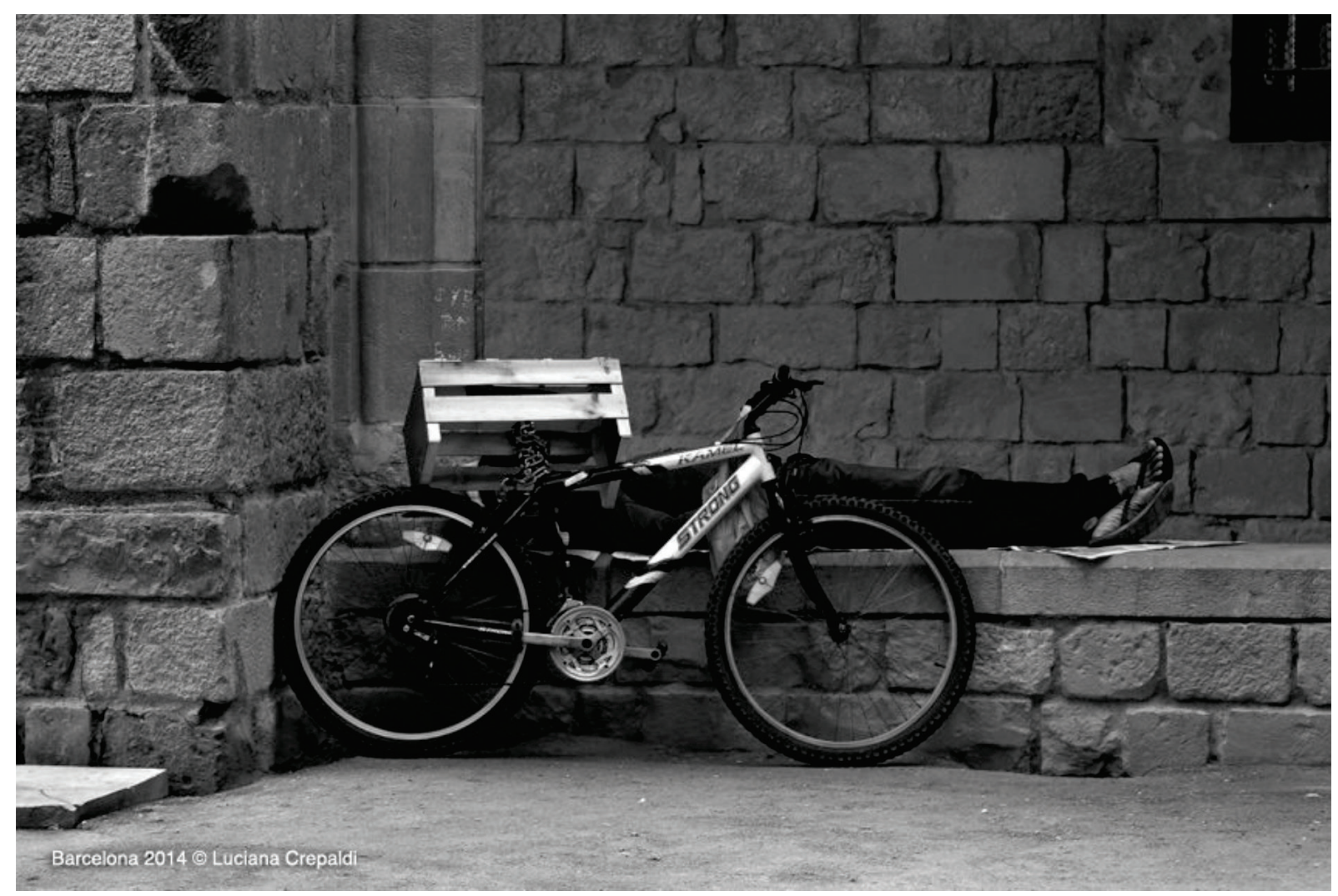

\section{El eterno retorno}

"Primer anuncio de la doctrina del eterno retorno al final del cuarto libro de La gaya ciencia: «Qué pasaría si un día o una noche se escurriese un demonio en tu soledad más solitaria y te dijera: "Esta vida, tal como la vives ahora y la has vivido, la tendrás de vivir otra vez, y aún incontables veces; y nada en ella será nuevo, sino que volverán de nuevo a ti todos los dolores, placeres, pensamientos y suspiros, todo lo indeciblemente pequeño y grande de tu vida, y todo en el mismo orden y sucesión: también esta araña y esta luz de luna entre los árboles, y también este instante y yo mismo. Al eterno reloj de arena de la existencia se le da una y otra vez la vuelta - iy tu con él, polvo del polvo!" ¿No... maldecirias al demonio que habló así? ¿O has vivido alguna vez un instante inmerso en el que le responderías: "eres un dios y jamás escuté nada tan divino!"?».

(Cit. en Löwith, La filosofía nietzscheana del eterno retorno (de lo mismo, Berlin, 1935), pp.57-58.) 


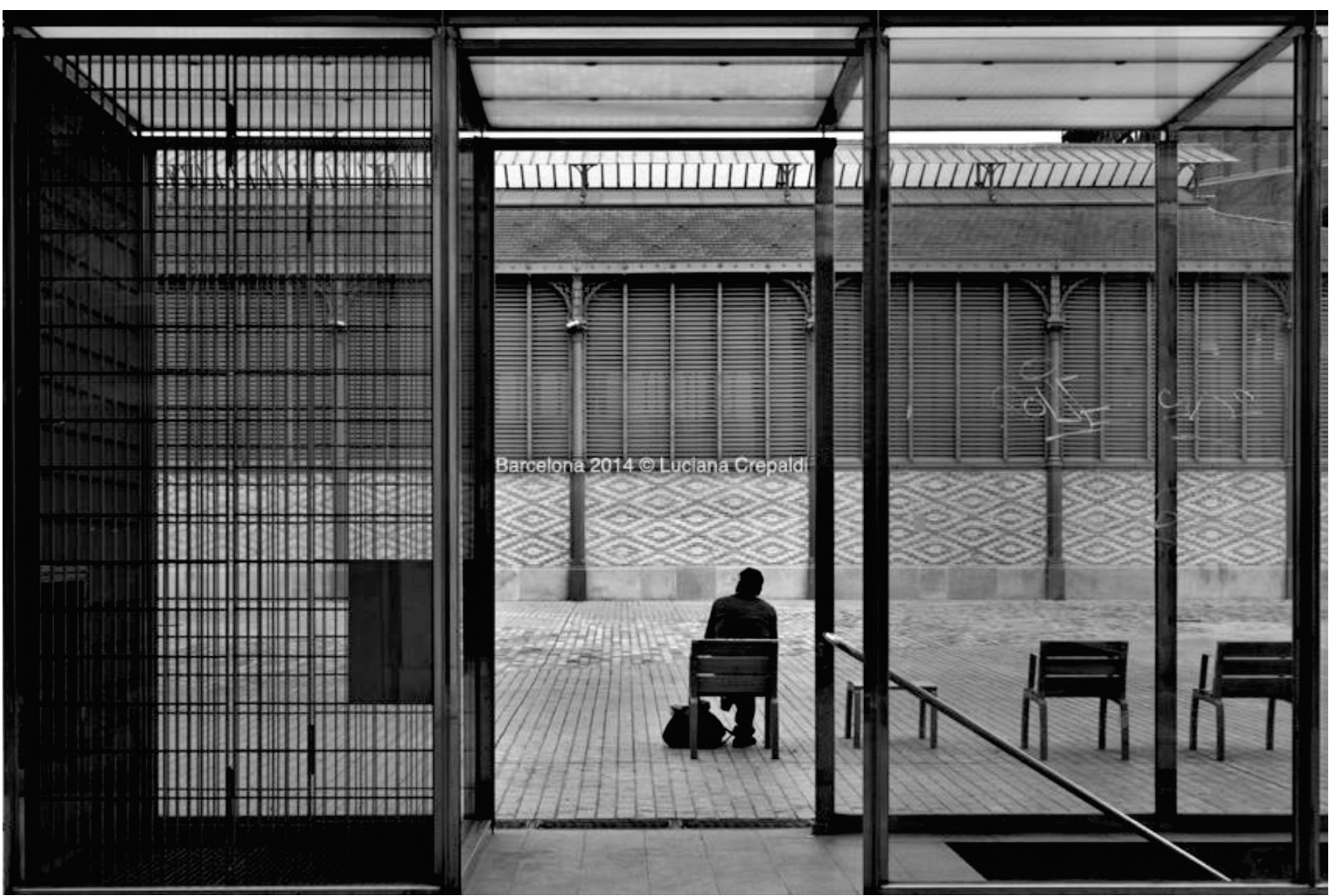

\section{Pensamiento unitario}

"Uno no debe dejar pasar el tiempo, sino que debe cargar tiempo, invitarlo que venga a uno mismo. Dejar pasar el tiempo (expulsarlo, rechazarlo): el jugador.

El tiempo le sale por todos los poros. -

Cargar tiempo, como una batería carga electricidad; el flâneur. Finalmente el tercero: carga el tiempo y lo vuelve a dar en otra forma - en la de la expectativa -: el que aguarda." 


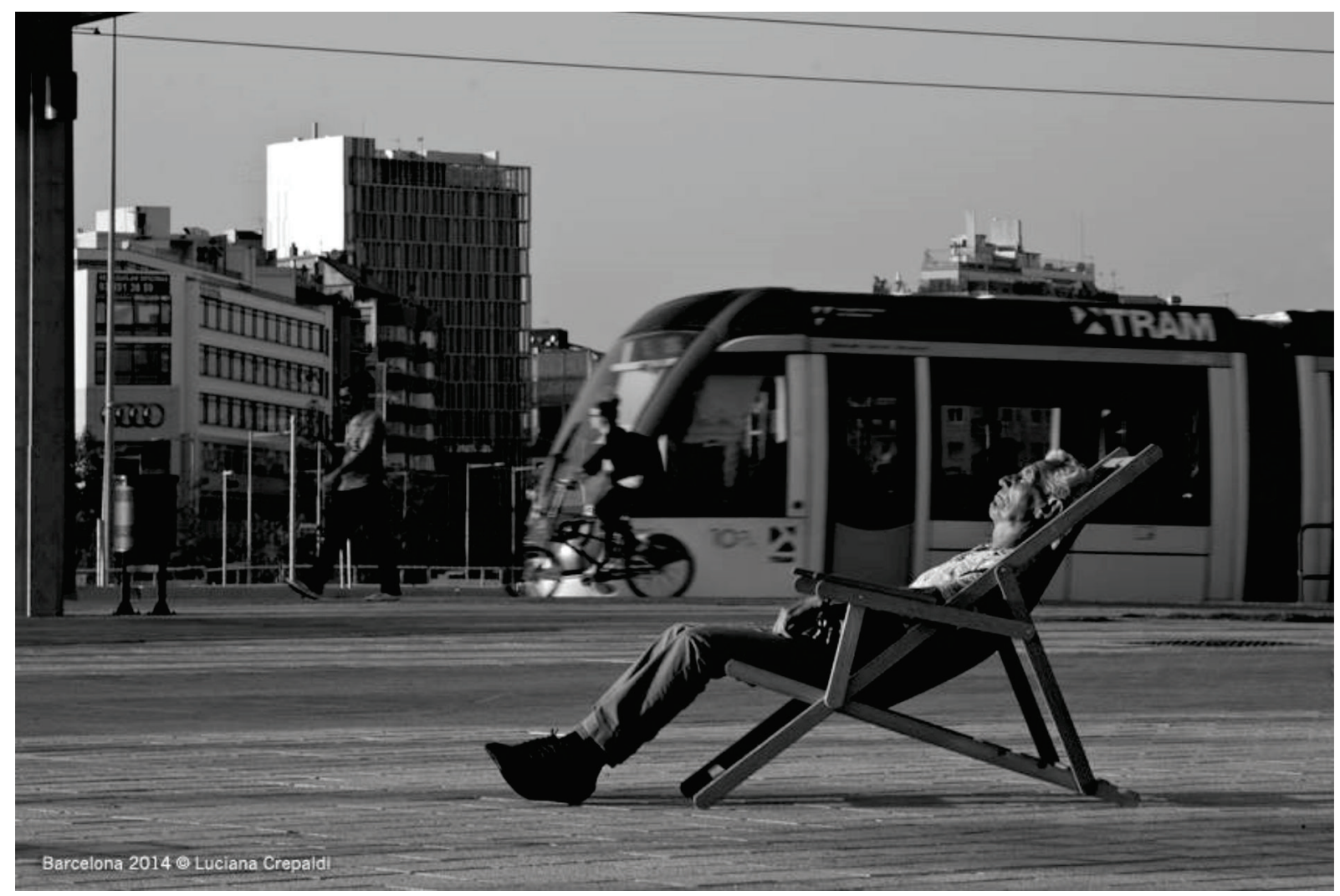

\section{Vivienda}

"Las calles son la vivienda del colectivo. El colectivo es un ente eternamente inquieto, eternamente en movimiento, que vive, experimenta, conoce y medita entre los muros de las casas tanto como los individuos bajo la protección de sus cuatro paredes. Para este colectivo, los brillantes carteles esmaltados de los comercios son tanto mejor adorno mural que los cuadros al óleo del salón para el burgués, los muros con el «Prohibido fijar carteles» son su escritorio, los quioscos de prensa sus bibliotecas, los

buzones sus bronces, los bancos sus muebles de dormitorio, y la terraza [del] café el mirador desde donde contempla sus enseres domésticos. Allí donde los peones camineros cuelgan la chaqueta de las rejas, está el vestíbulo y el portón que lleva de los patios interiores al aire libre; el largo corredor que asusta al burgués es para ellos el acceso a las habitaciones de la ciudad. El pasaje

fue para ellos su salón. Más que en qualquier otro lugar, en el pasaje se da a conocer la calle como el interior amueblado de las masas, habitado por ellas." 